\title{
Editorial
}

\section{Critical Political Anthropology of the Middle East}

This issue of $A M E$ focuses on the critical political anthropology of the Middle East. Studies of tribes and states have been on the agenda of political anthropology of the Middle East for decades, and in this issue we have various articles related to this topic. What is particularly informing in this issue are the brilliant articles concerned with informal politics going beyond statistical and formal studies, showing how power works through access to resources, and particularly the reproduction of political systems and hierarchies, and finally how modern legal systems within certain political structures are exercised in everyday life. Other fields of anthropology such as the anthropology of children and the anthropology of law may also benefit from this issue.

Pursuing an understanding of informal politics, one gets to the everyday life of politicians and their followers, the aesthetics of power, politics as ritual, and symbolic studies of signs and meaning. When this becomes a matter for a lineage to be a political one, the researcher has an open hand in consulting data, and in studying the topic in everyday life of a people, not only in their original homeland but also in the diaspora. This is what we see in Isabelle Rivoal's article where the personal dimensions of political life are disclosed, in rural and urban Lebanon as well as among migrants in Sydney, Australia. While the genealogy of the Jumblat family goes back to the eighteenth century, we see how the adaptation to modern socialist ideals has enabled the family to lead a nation into the twenty-first century. The art of adaptation has kept this family a viable choice for the people who need order and continuity to bear with upheavals. As an anthropologist the author pulls meaning out of everyday life, and not even an old piece of newspaper passes her critical eyes unnoticed.

Displacement and migration have always been exercised in the Middle East and during the past decades of prosperity of Kuwait, kafalah or sponsorship of migrants has been a legal means of defining a framework to organise 
the relationship between Kuwaitis and migrants, controlling and reproducing a specific hierarchical system. The people under the study conducted by Abdullah M. Alajmi are the Hadramis from Yemen who were migrants before the modern period, and the author's access to data on generations of Hadramis clearly shows continuity in the 'state of mind' on both sides of this relationship.

Critical political anthropology also takes a humane perspective to study law and the legal system and to see if human rights are really respected in the way heralded by modern states. There is nothing better than everyday life stories as the basis for research in this domain, and the uses made by Esther Hertzog of material from the media, social workers, schools, hospitals and personal life histories make evident that the law is used to enhance a legal welfare system which does not respond to people's basic rights. Thus law becomes a means of coercion violating human rights, and this critical stance is very important for the author, who studies the situation of children who are taken from their parents to be brought up within institutions or foster families.

As mentioned above, political anthropology used to be mainly concerned with tribal studies, but are tribal studies out of date today? Definitely not, as Marieke Brandt's article, which uses material from the tenth century (al-Hasan al-Hamadani), shows by examining qualities of tribal life such as malleability, which is seen in terms of having the capacity to divide or fuse, or, as is generally referred to, 'fission and fusion', which have made it possible for the tribal system to remain vivid. Having a shared genealogy and shared territory, the two essential binding elements are still vital concepts for understanding certain regions of the Middle East in the twenty-first century.

Finally a refreshing solution for many problems of difference across religious sects and ethnicities is analysed with respect to Iran by Christian Bromberger. The author shows how for the Tâlesh marriages between Sunnis and Shias are possible, and how the next generation can deal with this difference through girls having the adherence of their mothers, and boys that of their fathers. Thus everyday experience of each would dictate to them their alliance. Girls having lived more with mothers take up their adherence, boys having gone with fathers on daily activities and festivities, take on their religious adherence.

The book report by Erika Friedl is also related to this focus, as the relationship between sub-tribes in a village is related to a political event, the 1979 Revolution in Iran. The report shows the importance of tribal adhesion and loyalty during a critical period, and the everyday life of women and men is described in order to give face and background to this Revolution. The author of the reviewed publication, Mary E. Hegland, further uses the term 'tribe' as a key to understand the world in this context.

A point at the heart of questions of identity, tribe, kinship and politics is honour, which is addressed in the film report of this issue. 
In all of these articles we see methodological concerns of great value, as the authors have all used local texts and their works are not only anthropologically but also historically grounded. They have all been adept at using modern technology in their works for gathering data from mediators far away, or consulting sites intelligently. Finally the authors have been aware of topics of utmost interest in today's social sciences at large, such as identity, law and human rights.

- Soheila Shahshahani, editor 